\title{
New Inscription of Ilirian City Amantia as Political-Historical Source
}

\author{
Aleks Trushaj, Prof. Asooc \\ «I. Qemali » University of Vlora, Albania, Faculty of Human Sciences, Department of Education \\ alekstrushaj@gmail.com \\ Ermal Sina, Msc \\ «I. Qemali » University of Vlora, Albania, Faculty of Human Sciences, Department of Education \\ ermalsina@yahoo.it

\section{Lavdosh Jaupaj, Msc} \\ Archeological Institution, Tirane, Albania \\ ljaupaj@gmail.com
}

\section{Doi:10.5901/ajis.2015.v4n2p387}

\section{Abstract}

The Southwest of Albanian region, in Vlora region has lived in antiquity the Illyrian tribe of Amant. Amante developed their civic life by building cities and castles that identify their region. Their main town was Amantia, a political-administrative center from which depended even other civic centers Olympia, Treporti, Kanina or quays as Cerja, Matohasanaj etc. This was accomplished through a federal political form that was known as koinon. Self koinoni formed a separate state pyramid, because each unity that federates there, also had local government power. Amanties City is located near the present village of Ploce, in south-east of Vlora, between flow Valley Shushica in the right, and Valley Vjosa(Aos) in the river left. Regarding the etymology of the name Amantia, in English has a native word "stream, source ", which N.Joklin means" shore-river man"(bregalumas in Albanian). In the fourth century B.C, Amantia is definitely an important city in south of Illyria, in addition to his neighbor Bylys. In the III-rd century, Amante shed a coin in their own market. In the second century the city is included, along with Byllis in the Roman province of Macedonia in v. 148 BC. Romans many cities of South Illyria declared civitas libera, such that, even Amantia. From koinoni of amant, the earliest in the context of the Illyrian state, through new inscription is done more identifiable the extension and the hierarchy in koinon.

Keywords: Amante, Poinon, Inscription, Peripolark, Prytan

\section{Introduction}

\subsection{History of Amantia's people}

Amantia was the capital of the Illyrian tribe of Amant (or Abantes) located in the district of Vlora in southern Albania.Pseudo- Skylaksi throughout the llyrians region and Kaonia too, counts only two Illyrian cities: Amantia and Rizonin. According to him «Amantes are Illyrians from BYLINA». According to Pausanias, Amantia name comes from the Evoia - ABANTIA, that returning from the Trojan War through eight vessels, came to Keraune mountains and settled inside them (Pausania, 2002). Evoian presence in the region is also demonstrated by Plutarch, Pseudo-Skymnos and S.Bizantini. According to S. Byzantium (Bizantini, 2002), Amantia ('Auavtía) was an Illyrian city, near Orik and Corfu originating from Abantia returning from war Troy (Populis). Despite mythical the content it is important that Amantes for ancient Greeks were an Illyrian tribe. Regarding the etymology of the name Amantia, in English has a native word 'stream, resource', which is generally associated with Indo-European roots ab- dhe äp- 'water, river'.

Linguist B. Demiraj has rebuilt an ancient form « abna », for proto -Albanian language, which compares with the old Irish aub, and Latin amnis' river' (Demiraj, 1997). The name of the tribe for amantes residents, which has translated by Norbert Jokl was shore-river man"(bregalumas in Albanian) (Cabej, 1976). The city is located near the present village of Ploce, south-east of Vlora, between the right flow of Shushica Valley and in the left of Vjosa Valley, at a crossroads of communication from Vlora, in Sevasteri neck where joins the road coming from Byllis ( figure. 1 and 2) and continues towards Epirus. 


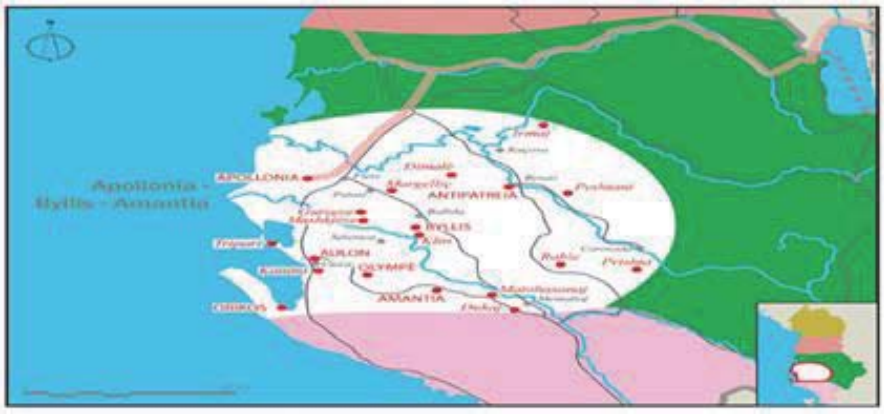

Figure 1. Apolonia - Byllis region - Amantia (C.A.A..)

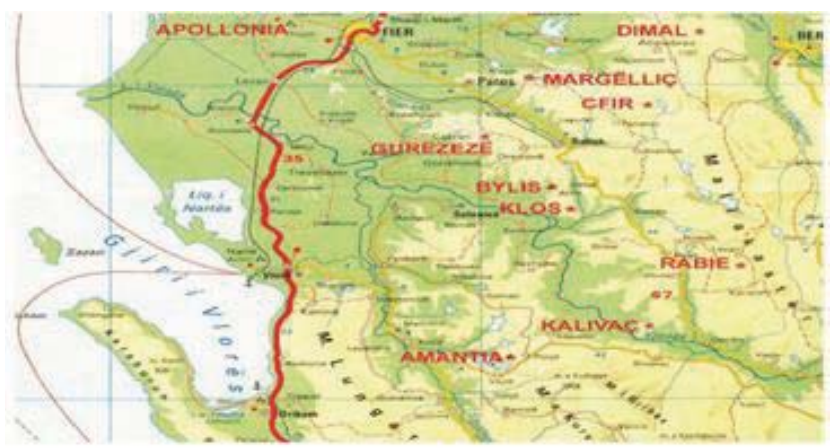

Figure 2. Geographic map of Apolonia - Byllis region - Amantia (C.A.A..)

This position makes Amantia an important crossroads in trade relations between the south coast of Illyria and interior regions. City with an area of 20 hectares is situated on an isolated rock plateau ( figure. 3-4), which stands at a height of 613 meters north-west of Mount Tartarean. He has a perimeter wall of my 2100 equipped with three monumental gates.

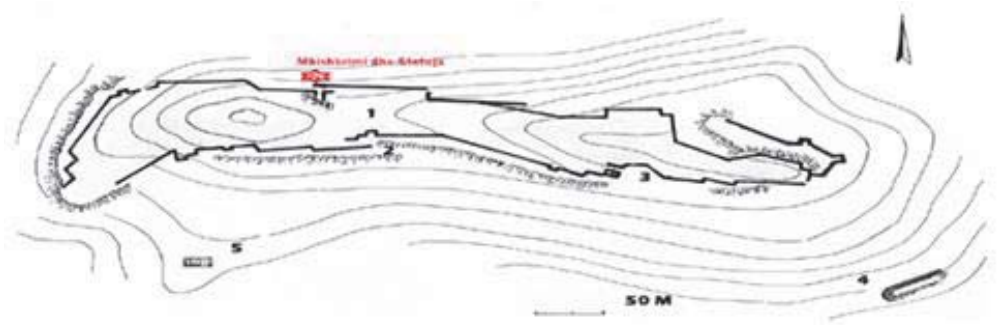

Figure 3. Plan of ancient city of Amantia

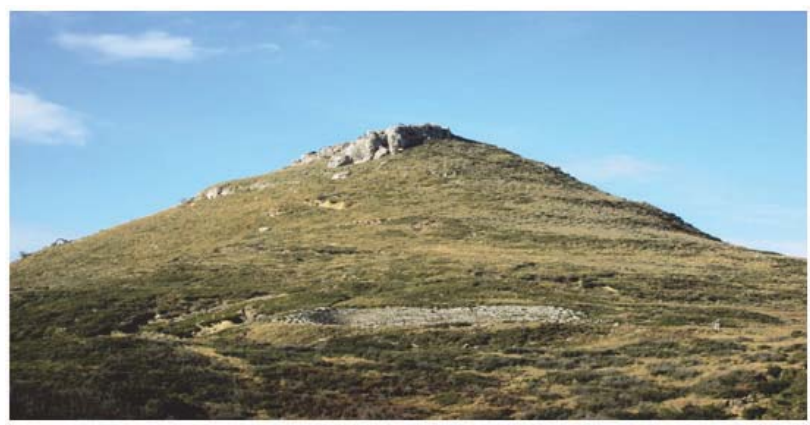

Figure 4. Photo by L. Jaupaj (2015) - panoramic view of Amantia hill 
In the south, the territory of amant communicates with Kaon neighbors, along the valley of the ancient Polianthesi (White River) or Shushica River today. Castle of Matohasanajt in east mark the extreme protection of amant in this direction. The city thought to be established from the $\mathrm{VI}^{\text {-th }}$ century $\mathrm{BC}$, but is mentioned for the first time in historical sources in the $\mathrm{IV}^{\text {-th }}$ century BC.In the fourth century BC Amantia is definitely an important city, which at the beginning of the III-rd century BC is absorbed into the kingdom of Pyrrhus. In the III-rd century B.C Amantia became the main center of the community of amant. Amante regained their independence and throw a coin market around 230 BC. They are invited by the Delphi Theora to enter in competitions as indicated by their name in the list of theraodoces. In the second century there is no information, but the city is included, along with Byllis in the Roman province of Macedonia by 148 B.C. The Roman cities of south Illyria are announced civitas libera . In the period of Antony, Amantia recognizes a certain prosperity as indicated by an inscription of the second century A.C, written in two languages, Greek and Latin, in the village of Ploce, which mentions the construction of a public granary of the Roman citizen Publius Pomponius Aelianus (Ceka, 2005).

Using this inscription of Greek and Latin language proves the presence of a bilingual community, certainly a Latin enclave and an administration run by decurions. The city is still active at the time of Justinian I, where it undergoes a repair of fortifications (Procopii, 2002).

\section{Research Methodology}

For the realization of this paper are used several methods of study, such as research in the field and specifically in Amanti, Cerje, Matohasanaj. Amant area surveillance, measurement and photography as in Amanti, Matohasanaj are made through collaboration between archaeologists A.Trushaj, E.Sina and L.Jaupaj. An important support have been written sources of ancient authors and publications made by Albanian and European archeology over the region and beyond.

\section{Socio-political Organization According to Epigraphic Sources}

Epigraphic and numismatic data confirm that Amantia in IV-th century B.C is transformed into an important center in southern Illyria. In this period takes the full shape Acropolis. Surrounding the city over terraces the city develops where that are established the constructions of public nature. It should be expected third century where city is better known to social - political development. In this period, as well as other centers of Illyria and Epirus to strengthen the state match Illyrians under Taulants dynasty and especially the rule of Pyrrhus, Amantia recognize a International Development not a decline. This is the period when the city knows a great International Traders Development playing a role in local exchanges the monetary denominations on behalf of it.

In this period we also have Prytan which sets its mark bronze coins. Amanti developed the activity of their socioeconomic and political center under federal organization with centers around the epigraphic sources known as koinon.Amant civic community belonged Olympies town in north-west (in the village of Mavrovo today).Amantes raised castle in south and east Ceries rose Matohasanaj castle in the village, about $14 \mathrm{~km}$ away of amanties.In the region of amant flourish ancient city of Orik and Aulona.Koinoni of amant was a politico-territorial communities that relied on cities and castles around, with the capital city of Amanties.

Koinoni was included in the historical events of the time .According to Pausanies in this territory in 460 B.C is conducted a war against amant Apollonia, who calls Abantia, whose center was Thronioni (Kanina today), a fortification protourban who survived along Amanties. Apollonia people devoted a work of art this victory (in Olympia of Peloponez) conducted by Lyku Mironit son. «Here we are as a gift of Apollonia, built near the Ionian by Foibi haired, winners against Zeus Abantia ,we dedicate him a tenth of the spoils to get in Thronion» (Pausania, 2002). This moment of conflict in the history of relations between the colonists of Durrahas and Apollonian people and their neighbors would be an exception.Good relationship would provide ancestors a new home while to the secodaries the model of a new society. Unlike state monarchical superstructure Illyrian koinōnia had a democratic organization with a central administration composed of elected officials every year. Koinoni itself formed a separate state pyramid, because each unity that federate there were also local government. So the Koinon of Amant, the earliest in the context of the Illyrian state, through inscriptions recognize the higher authorities, ecclesi-legislative council; damiorgie-Federal Council; prytani-executive chairman Koinon, military officers, army commander strategist, hiparc- commander of the cavalry; polarc peri-commander of the border guards etc.

The inscription found in October 2014 by landslides, unveiled a plaque limestone with more value for prytanit role in the city but also for his onomastic data. He as leader of the city council, bud, built, of course, a monument that was at 
the center of the city, after the inscription is missing its end, so what he built. According to tradition there were public buildings and city decisions written on stone tablets to be read by the public. Very likely the tiles have been placed near the monument intagruar or build from prytani. It cannot be excluded that he has rebuilt the city wall, in the northwestern part of it, but finding a statue of the Roman period are the slide of the earth became more reliable than those coming from the city center (agora) (figure. 5).

The inscription is located in the central part of the plate with dimensions $72 \mathrm{~cm} \times 36 \mathrm{~cm} \times 8 \mathrm{~cm}$, located more on its left side, almost four equidistant lines. The height of the letters is $2.5 \mathrm{~cm}$; and writing of a frequent form found in IV-th-III-rd centuries B.C.

\section{ПPYTANEYWN}

\section{ZШПYРОС}

\section{ПAPMENICKOY}

KATECKEYACE

I.1: «Being as prytane » ose « As prytane » (a participle masculine nominative singular , for this is mputaveúwv

I.2: «Zôpyros », is a well known name in the Greek world also frequent in southern Illyrian and Epirus, especially in Durrhachion dhe Apollonia.

I.3 : « son of Parméniskos » is a well known name in the Greek world also frequent in southern Illyrian and Epirus, as well as Apollonia coins dhe Dyrrhachion dated 229-100 B.C.

I.4: « has constructed» (if given a monument or building of fortification wall !! after missing what he has built) This is explained differently if he has been integrated into the monument.

So this inscription can be translated: « as he was a prytan, Zôpyros, son of Parméniskos, has constructed»

Who was Prytan « Zôpyros »

Zôpyros, a typical Greek name but widespread not only in Amantia but wider in South Illyrian especially in the Greek colonies of Durrhachion and Apollonia. The $\mathrm{III}^{\text {rd }}-\mathrm{Il}^{\text {-nd }}$ century B.C correspond with the period of greater openness to Greek culture, which show two Greek imports; urban development with Greek buildings (theaters, stadiums) and onomastics.

In this historical context, where elements of acculturation are highlighted throughout the region, especially in the Hellenistic period, the patronymic name Parméniskos Zôpyros expresses an important element of Greek onomastic Amantia. It is not a coincidence as the presence in the stadium reinforces this acculturation level.

This does not mean that we have an assimilation but adaptation with the dominant culture at all levels of life, a form of «Greek modalism» typical for the period starting from Alexander the Great and installed in the region of Epirus Pirrua. This explains the fact that Amante has been invited by the Delphi Theora, because nothing separated from this "modalism».

Although at first glance have a Greek name, does not mean that its Parméniskos and Zôpyros are ethnically Greek but what their name allows us is the fact that the elite of Amantias was in a high degree of acculturation level. As in the Greek language throughout the Mediterranean world is using or writing copy for their language as to Messapii or it is used as an official language by non-Greek peoples as is the case of Amantias and all Illyria and Epirus. »

Thus, Zôpyros is one Amantia's people who has known Greek culture, already installed in the region. The Social and political life within koinoni was not «barbarian». Roman Historian of II-ND century B.C. Justin continued to call barbarous even the cultured king Pirro. The same setting is used by Plini (Plini, 2002) for the residents of the two provinces most civilized of Southern Illyria, which calls «barbar of bylliones et amantis ». But in their capitals, in Byllis and Amanti, these barbarians « loved social life » as it is expressed Skymni (Scymni, 2002).

Other findings near the inscription.

Also because of landslide were gathered together two parts of a statue constructed by limestone.

The Statue: composed by two parts $60 \mathrm{~cm} \times 50 \mathrm{~cm} \times 40 \mathrm{~cm}$; lace holes distance is $12 \mathrm{~cm}$ (figure. 6, 7).

Two parts combine to form its bottom. It represents a person sitting where tunik sides are clearly distinguished. The two parts associated with cramps lead, covered after bonding to form a single body. Traces are still preserved as the left and the right.

By the first part of the two legs is distinguished a person who sits. Between the two legs the part the cloth falls down to close heels. Feet are not saved, and it seems the place of their establishment. Difficult to identify the gender, could be of a public character of the city. The reverse side is cut straight and without work by identifying its position. Undoubtedly it has been endorsed and not visible to the public. The technique of working dating without doubt the Roman era. 


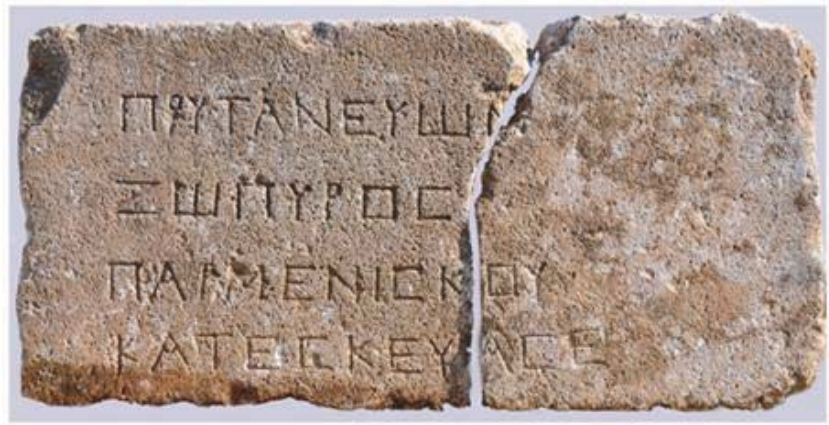

Figure 5. Inscription, E. Sina (2015)
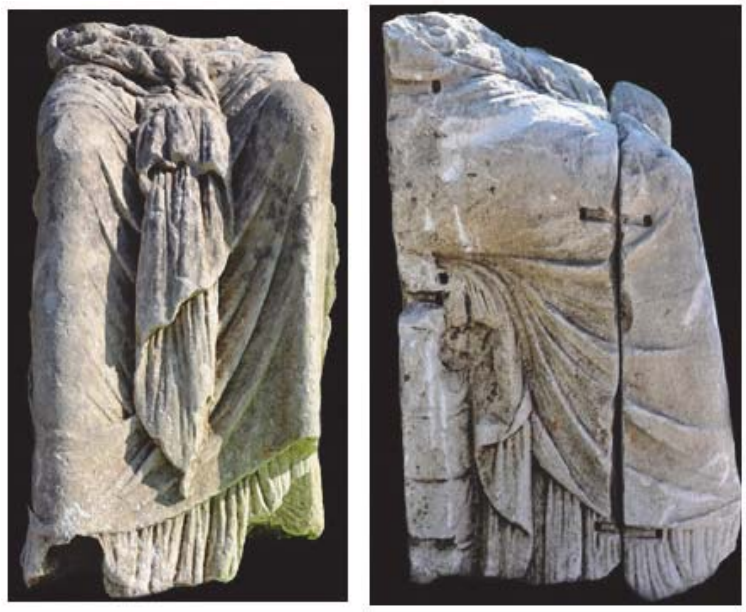

Figure 6. The statue seen in front (E. Sina)

Figure 7. The statue seen on the left (E. Sina)

Another inscription comes from the eastern periphery of the amant territory.

In the east of the city of Amanties was built an ancient castle that today is in the present Matohasanaj village. Its construction provided amant koinoni protection on that side where regular garrisons of soldiers were stationed specifically under the direction of military commander or peripolarc. An incomplete inscription found on the wall of the castle talking about it.

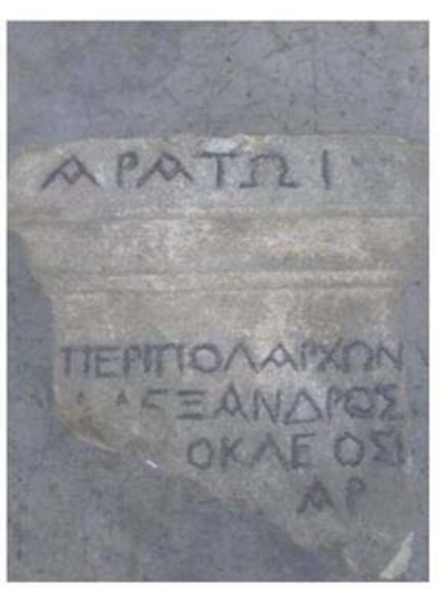

Figure 8.a. Inscription form (A.Trushaj)

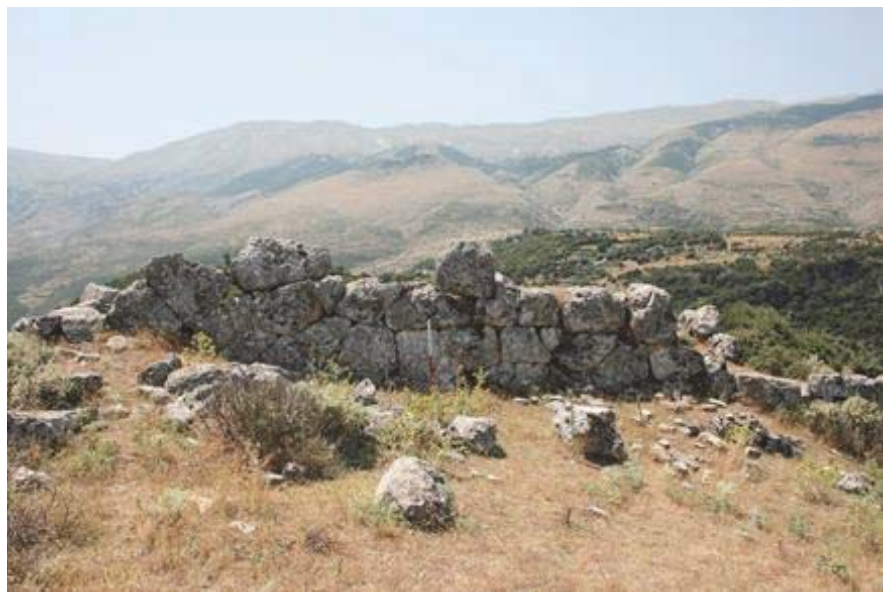

Figure 8.b. Matohasanaj region (A. Trushaj) 
The inscription is carried on a limestone slab about $25 \mathrm{~cm}$ tall and $20 \mathrm{~cm}$ wide with the exception of the head of this koinisku that goes up to $24 \mathrm{~cm}$ width. Plates in her head is decorated in relief with a stripe lined (figure.8.a.b). By its form it looks like a votive stone where the inscription consists of five lines, as follows:

\section{APATSI

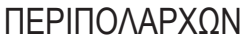 \\ $\mathrm{A} \wedge \mathrm{E} \equiv \mathrm{AN} \triangle \mathrm{PO} \Sigma \mathrm{I}$ \\ OK\EOEI}

Its content has more or less this sense:

1.1. ApatwI - constructed

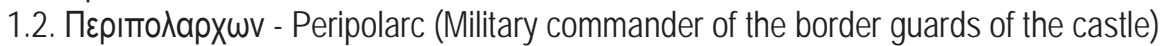

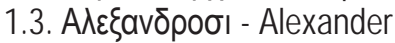

1.4. Ок $\lambda \varepsilon 0 \sigma \mathrm{I}$ - glorious

1.5.A $\mathrm{p}$ - are indeterminate initials.

The inscription shows a kind of dedication(stel tomb) to Perpilarc (commander) of Alexander the Great. Generally translated; " Peripolarc Alexander the Great constructed »

Which Alexander? Commander of the garrison, or may be Alexander of Macedonia, cousin of the Illyrians. We know that this region has under his rule for a long period of time. Recognition of this castle is not only related to the time of his ruling, but also to Alesander Mollosit.

Heir of Pyrrhus of Epirus, Alexander $\|^{-n d}$ spread its authority in these areas. But this inscription of the Hellenistic period in addition assumptions is related primarily to the military commander or Peripolarc of this military unit that guarded in this corner of Koinoni of Amant. This inscription belongs to an Illyrian Amant with military functions, and precisely to that of Peripolarc.

\section{Conclusions}

Amant were an important tribe in South Illyria that passes the urban life since the fifth century BC.

In their area, many civic center florished and even rural ones. The conflict with apollonian destroyed one of their centers Thronioni, which was rebuilt during the time of Pyrros of Epirus, who stretched his rule until AOS (Vjosa), but with a different name Olympe.

The main center was the city of amant, Amantia who continued its political-economical life up to barbarian occupations.

Amante people of their area, joined in a single unit political-territorial one, called Koinoni.

Other centers around the city of amanties had their representatives in the council of Koinoni, they used their currency cut by the city amanties, vigilate in military peripheral garrisons of koinoni, as the fortress of Kanina, Matohasanajt, Cerja etc.New inscriptions from amant zone identify for the first time the functions, public officials and military of this koinoni such as prytani of Zopyros or Alexander Peripolarc while referring to analogy with today's political shape of Apollonian people or with Koinoni of neighboring Bylynian.

The new data fill the void created for the real recognition of the historical activity of amant Illyrian-policy.

\section{References}

Bizantini S. De Urbibus Et Populis, Illyrian and Illyria on ancient authors,(2002) Toena, Tiranë,pp.416-422.

Ceka N. (2005). ILIRËT, Migjeni, Tirana,pp.197-215.

Çabej E. (1976). Studime etimologjike në fushë të shqipes, Academy of Science. RPSSH, Tirana, Albania,pp.30-43.

Demiraj.B (1997). Albanische Etymologien: Untersuchungen zum albanischen Erbëortschatz, Amsterdam, pp. 50-83.

Justini, I,Historiarum Philippicarum Pompei Trogi, and Illyria on ancient authors,(2002) Toena, Tiranë,pp.291-306.

Pausania, Descriptio Graeciae,V,22.3-4, Illyrian and Illyria on ancient authors,(2002) Toena, Tiranë,pp.246-247.

Plini C. Naturalis Historiae,23, Illyrian and Illyria on ancient authors,(2002) Toena, Tiranë,pp.192-200.

Procopii C, De aedificis,V, 4-3, Illyrian and Illyria on ancient authors,(2002) Toena, Tiranë,pp.437-445.

Scymni Ch,OrbisDescriptio,420, , Illyrian and Illyria on ancient authors,(2002) Toena, Tiranë,pp 72-73. 